\section{MKN-10 - AKTUALIZACE 2018 A STRUKTUROVANÝ OBSAH KLASIFIKACE}

\section{Petra Przeczková, Dalibor Slovák, Miroslav Zvolský}

Mezinárodní statistická klasifikace nemocí a přidružených zdravotních problémů, dále jen MKN, (v originále International Statistical Classification of Diseases and Related Health Problems) je publikace spravovaná Světovou zdravotnickou organizací (WHO), která kodifikuje systém označování a klasifikace lidských onemocnění, poruch, zdravotních problémů a dalších příznaků, situací či okolností.

Původně vznikla publikace $v$ roce 1893 jako Klasifikace příčin úmrtí a jejím cílem bylo umožnit mezinárodní srovnání záznamů o úmrtích. WHO převzala odpovědnost za klasifikaci roku 1948 a počínaje šestou revizí klasifikace, o níž jednala $v$ roce 1949 konference $v$ Paříži, započala přeměna klasifikace v univerzální seznam diagnóz. Klasifikace se postupně stala všestrannou pomůckou např. pro řizení zdravotní politiky nebo při vykazování péče zdravotním pojištovnám a obdobným platebním systémům. 43. plenární zasedání Světového zdravotnického shromáždění WHO se usneslo přijmout MKN ve znění desáté decenální revize s novým názvem "Mezinárodní statistická klasifikace nemocí a přidružených zdravotních problémů" (MKN-10) s účinností od 1. 1. 1993. V České republice probíhaly prípravy na použití MKN-10 ve spolupráci s řadou odborníků, včetně zástupců českých odborných společností, a klasifikace nabyla platnosti od roku 1994. V roce 2004 vydala WHO druhé aktualizované vydání MKN-10, na jehož základě vznikla druhá aktualizovaná verze českého vydání MKN-10, v roce 2016 pak vydala zatím poslední vydání, ze kterého vychází i aktualizovaná verze překladu MKN-10 pro rok 2018.

Přepracované verze klasifikace vycházejí zhruba s desetiletou frekvencí a odlišují se číslem uváděným za zkratkou MKN (např́klad MKN-9, MKN-8 apod.). Pro nynější desátou revizi byl schválen aktualizační proces, který prodloužil její platnost dalece za obvyklých deset let. Od roku 1996 jsou Světovou zdravotnickou organizací vydávány pravidelné roční aktualizace, přičemž změny s větším dopadem (přidání či zrušení kódu, přesun položky apod.) vycházejí jen jednou za tři roky (naposledy v roce 2016). V České republice bylo poslední tištěné vydání MKN-10 publikováno v roce 2008, neobsahovalo však Instrukční príručku, která byla publikována naposledy v roce 1996. Následné aktualizace v letech 2012, 2013, 2014 a 2017 byly zveřejněny pouze $v$ elektronické podobě.
K 1. 1. 2018 vstoupila v ČR v platnost nová verze MKN-10, ve které došlo k rozsáhlým změnám ve všech třech svazcích. Tato verze obsahuje nejen aktualizace provedené na úrovni WHO v letech 2015-2017, ale také změny aplikované Ústavem zdravotnických informací a statistiky ČR (ÚZIS ČR). Vzhledem k tomu, že MKN-10 se snaží zachytit jazyk moderní medicíny a zároveň ho i zpětně ovlivňuje, musí být jejím smyslem i jazyková kultivace. Ze strany ÚZIS ČR proto došlo nejen k opravě pravopisných, typografických a stylistických chyb, ale také k částečnému terminologickému sjednocení. Publikace je dostupná jak v tištěné, tak elektronické podobě. Veškeré elektronické podklady jsou k dispozici na webové stránce http://www.uzis.cz/katalog/ klasifikace/mkn.

\section{Struktura MKN-10}

Komplexní publikace MKN-10 se skládá ze tří svazků, kterými jsou:

\section{I. svazek - Tabelární část}

Obsahuje hlavní klasifikaci rozdělenou do kapitol podle tělesných systému. Samostatné kódy daného bloku se poté dělí na úrovni třímístných a čtyřmístných položek. Klasifikace dále obsahuje patřičné a nepatřičné termíny, klasifikaci morfologie novotvarů, stručné seznamy pro tabelaci úmrtnosti a nemocnosti, definice a pravidla pro nomenklaturu.

\section{II. svazek - Instrukční příručka}

Samostatný svazek usnadňuje manipulaci s klasifikací. Obsahuje pravidla pro záznam a kódování nemocnosti a úmrtnosti, praktické aspekty používání klasifikace a speciální tabelační seznamy.

\section{III. svazek - Abecední seznam.}

Obsahuje abecední seznam položek s úvodem a rozšířeným návodem k používání.

\section{Provedené změny v Tabelární části MKN-10 s platností od 1. 1.2018}

\section{Nové a zrušené kódy}

Na základě aktualizací ze strany WHO došlo k novému přidání nebo zrušení kódů. Je ale nanejvýš důležité upozornit, že v České republice není možné nově přidané kódy použít pro účely vykazování hospitalizační péče do doby, než dojde k zapracování změn do klasifikace hospitalizačních případů. Pokud přesto

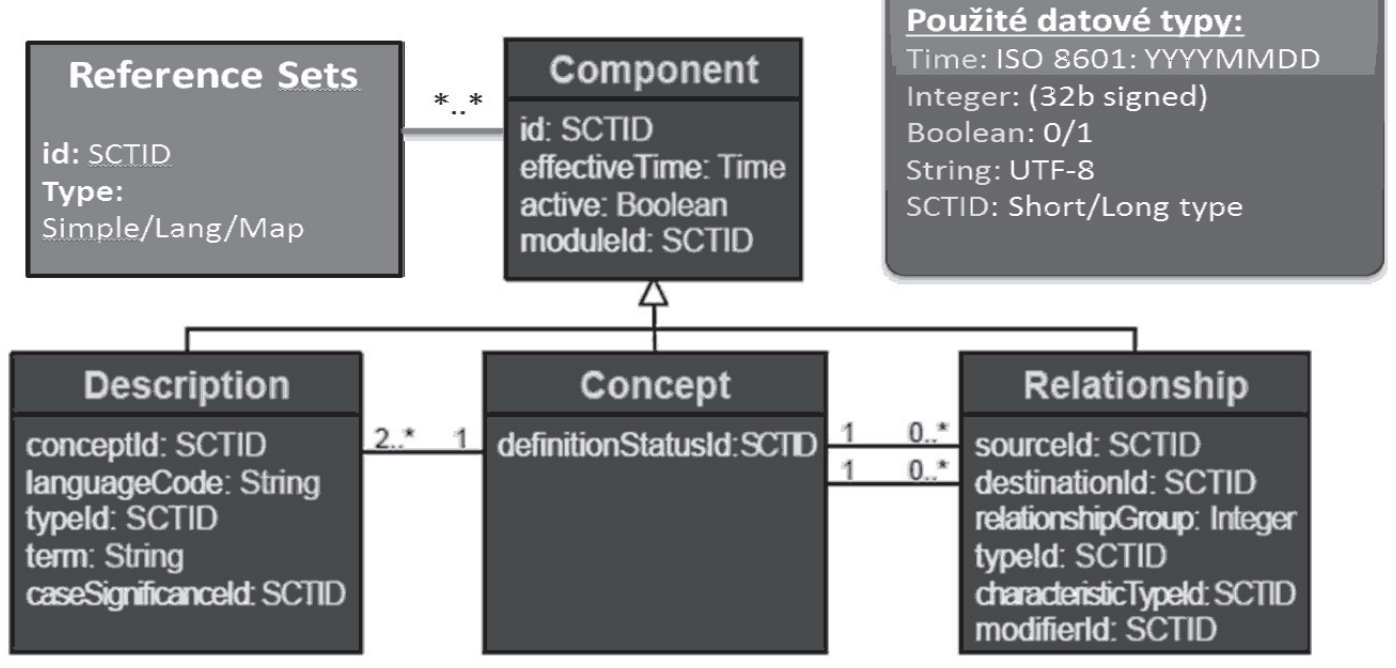

Obrázek 1 


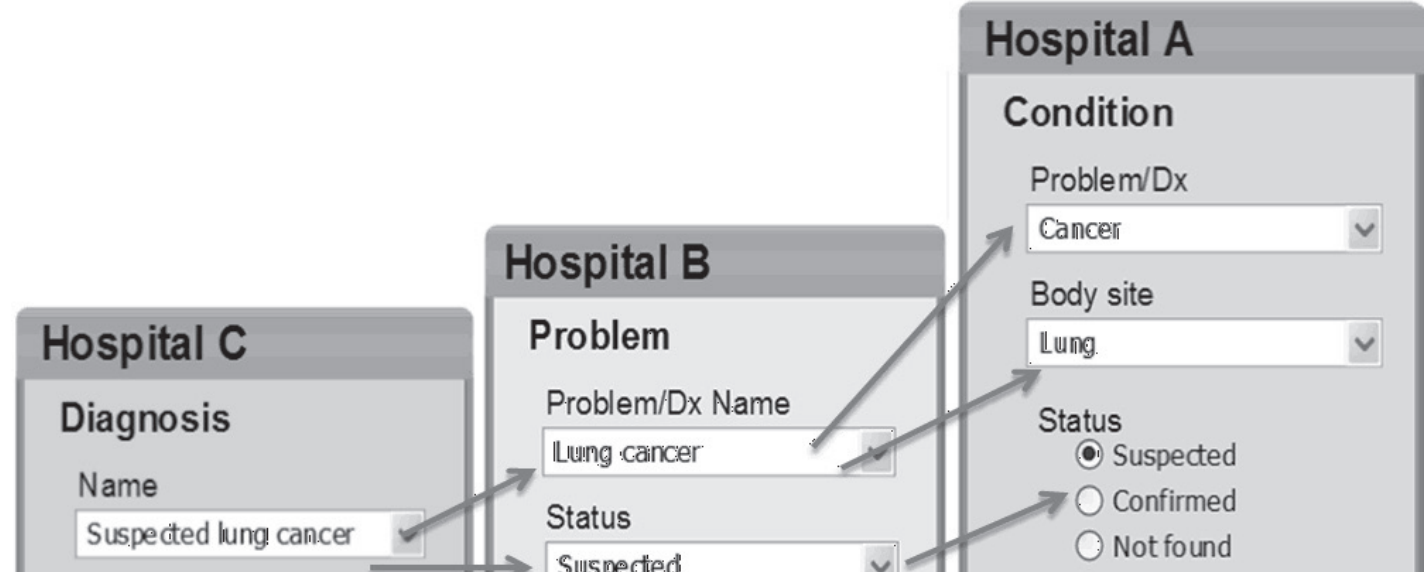

Obrázek 2

*) Jest žalostné, jak nejen širši publikum, ale bohužel i samotni vědei se někdy divají na knihovníka. Knihovník je jim v knihovně asi tím, čím je řeknĕme ve škole - skolnik; anebo ani to ne. Prostě zřízenec sázejíci knihy do polie. Slyšeli jsme nedávno, jak se jeden učenee s úsměškem pozastavil nad tím, že knihovniei potřebuji chodit do té své školy d v a rok y! Když mají i jinak skutečně vzdělaní lidé

BVTTOZAR YEVOLE-KARELREZICKA

BIBLIOGRAPHIA MEDICA

ČECHOSLOVACA

VOL. I. -1947

PRAGAE 1040 
dojde ze strany poskytovatele zdravotních služeb k jejich vykázání, případ se může zařadit do chybové DRG skupiny 99990.

Z tohoto důvodu jsou v Tabelární části pro lepší orientaci nově přidané kódy vyznačeny symbolem $>$ a odkazem na stránku 24, kde je toto upozornění na omezení v použití uvedeno.

Pro príklad si dovolujeme uvést některé nově přidané a zrušené kódy:

\begin{tabular}{|l|l|}
\hline $\begin{array}{l}\text { Příklady zrušených } \\
\text { kódů }\end{array}$ & Příklady nově přidaných kódů \\
\hline $\begin{array}{l}\text { A90 Dengue [klasická } \\
\text { forma dengue] }\end{array}$ & $\begin{array}{l}\text { G23.3 Mnohočetná systémová atrofie, } \\
\text { typ s převažujícím mozečkovým } \\
\text { syndromem [MSA-C] }\end{array}$ \\
\hline $\begin{array}{l}\text { G90.3 Multisystémová } \\
\text { degenerace }\end{array}$ & $\begin{array}{l}\text { G83.5 Syndrom uzamčení (locked-in } \\
\text { syndrom) }\end{array}$ \\
\hline $\begin{array}{l}\text { Z22.5 Přenašeč (nosič) } \\
\text { virové hepatitidy }\end{array}$ & $\begin{array}{l}\text { L98.7 Nadmíra a nadbytek kůže } \\
\text { a podkožní tkáně }\end{array}$ \\
\hline
\end{tabular}

Tabulka 1

\section{Terminologické změny, opravy typografické a pravo- pisné}

V rámci aktualizací ze strany ÚZIS byla odstraněna řada typografických a pravopisných chyb. Všechny tyto změny v používané terminologii byly konzultovány $s$ expertem na medicínskou terminologii a obvykle i s lékařem z daného oboru. Vzhledem k tomu, že úplné sjednocení terminologie by mělo velký dopad na používání klasifikace $v$ praxi, jsou komplexní změny plánované až v rámci překladu MKN-11. K vyjasnění a zpřesnění došlo přibližně v padesáti terminologických otázkách, např. respirační - dechový - dýchací. Celkově pak bylo provedeno přibližně 1500 změn vztahujících se k úpravě terminologie, viz příklad níže.

\section{Sjednocení používání latinských a anglických termínů}

Následkem probíhajícího vývoje překladu a prováděných aktualizací MKN docházelo také k různému užívání názvů a termínů. Za účelem částečného sjednocení se v nynější aktualizaci nastavily základní pravidla pro použití latinských a jiných cizojazyčných termínů v názvech daných položek. Jedná se o tyto podmínky použití:
a) latinské a anglické termíny jsou nyní uvedeny v hranaté závorce
b) počeštěné termíny pocházející z latiny jsou nyní uvedeny v kulaté závorce
c) rovnocenná synonyma jsou oddělena pomlčkou

$\checkmark$ rámci tohoto sjednocení používání termínu v názvech položek bylo provedeno celkem 668 změn, viz príklad níže.

\section{Provedené změny v Abecedním seznamu MKN-10 s platností} od 1. 1. 2018

Změny provedené v Abecedním seznamu paralelně navazují na úpravy Tabelární části, dále obsahují aktualizace provedené ze strany WHO a také drobné textové opravy. Z celého obsahu je pozměněno $6 \%$ řádků, které však ve výsledku činí přes 3,5 tisíce změn. Jednou z nejrozsáhlejších změn bylo přidání hesla Stavy vzniklé v perinatálním období, které obsahovalo 1860 nových rádků.

Provedené změny v Instrukční příručce MKN-10 s platností od 1. 1.2018

Značných změn doznala rovněž Instrukční příručka, kde na rozsáhlé změny schválené WHO navázala $v$ českém vydání velká pravopisná, stylistická a terminologická revize. K výrazným změnám došlo $v$ užívané terminologii kódování mortality, např::

$\begin{array}{lll}\text { Vyvolávajicípríčina } & \\ \text { Přimýd důsledek } & & \text { Výchozíbod } \\ & \text { \# } & \text { Zjevná príčina }\end{array}$

Pravidla pro výběr předchozí príčiny

Pravidlo 1

" Nalezení výchozího bodu

Pravidlo C. Vazba $"$ Krok SP4

» KrokM1-Zvláštní pokyny

Povaha poranění » Hlavní poranění

Plánované aktualizace a změny $\mathbf{v}$ českém překladu MKN-10

$\mathrm{V}$ rámci unifikace terminologie je jednou z plánovaných aktivit další rozsáhlejší kultivace Abecedního seznamu, která bude následně publikována pouze $v$ elektronické podobě. Kultivace by měla řešit další sjednocování terminologie, doplnění synonym a především chybějících termínů.

Změn se v roce 2018 dočká také interaktivní prezentace (browser) klasifikace, který je nyní dostupný na adrese https:// www.uzis.cz/cz/mkn/index.html. Cílem je zvýšit interaktivitu, napojit další zdroje (pravidla a doplňující seznamy z Instrukční př́ručky, pravidla z národních metodik) a zjednodušit a zefektivnit možnosti vyhledávání tak, aby se z uvedeného portálu stal nástroj pro běžné použití kodéry v klinické praxi.

Do závěrečné fáze už dospěly i prípravy MKN-11, která bude v letošním roce na úrovni WHO oficiálně schválena. Poté se v ČR zahájí proces překladu a implementace, který odhadujeme přibližně na pět let. Během něj by měla být připravena česká verze, ale také upraveny navazující mechanismy pro ukládání a sběry dat, např́klad metodiky vykazování dat plátcům péče a pro statistické účely.

\section{Kontakt:}

Petra Przeczková

Ústav zdravotnických informací a statistiky ČR Univerzita Palackého v Olomouci

\section{Dalibor Slovák}

Ústav zdravotnických informací a statistiky ČR 1. LF UK

\section{Miroslav Zvolský}

Ústav zdravotnických informací a statistiky ČR 1. LF UK 